\title{
Has the world caught on the Responsibility to Protect? Revisiting the Rwandan Genocide 25 years later
}

\author{
Roche Christine C. Angeles $^{1 *} \&$ Sharon Mendoza-Dreisbach ${ }^{2}$ \\ ${ }^{1}$ Helena Z. Benitez School of International Relations and Diplomacy, \\ The Philippine Women's University, Manila, Philippines \\ ${ }^{2}$ Schoolof Business, Skyline University College, Sharjah, United Arab Emirates \\ *e-mail: 2018t1400@pwu.edu.ph
}

Received: 12 May 2020; Accepted: 10 December 2020; Published: 11 December 2020

To cite this article (APA): Angeles, R. C. C., \& Mendoza-Dreisbach, S. (2020). Has the world caught on the Responsibility to Protect? Revisiting the Rwandan Genocide 25 years later. EDUCATUM Journal of Social Sciences, 6(2), 35-41. https://doi.org/10.37134/ejoss.vol6.2.4.2020

To link to this article: https://doi.org/10.37134/ejoss.vol6.2.4.2020

\begin{abstract}
Twenty-five years after the tragic Rwandan genocide that killed around one million people in 1994, this paper revisited the tragedy by looking into the contemporary narratives on genocide studies. Through a document analysis of the existing discourses regarding the genocide, the authors found that leading scholars in international politics recognized the failure of the international community in the prevention and mitigation of the conflict following the lack of international political will by the United Nations Security Council. They have recognized that each state has the moral responsibility and obligation to protect the human rights of all of humanity. Moreover, following the trend of decreasing global democracy, scholars have also warned us that more mass atrocities may happen with the rise of authoritarian leaders in this current juncture of our history. As such, the responsibility to protect must actively prove its purpose to protect people from torture, slavery, war crimes, and genocide.
\end{abstract}

Keywords: Rwanda, United Nations Responsibility to Protect, human rights, genocide

\section{INTRODUCTION}

At a time of historical uncertainty in postcolonial Africa, Rwanda became known internationally when genocide was done by the Hutu tribe on the Tutsi ethnic group. The decolonization efforts of former European colonial powers in the 1960s created a power vacuum between the two mentioned competing groups in the country. The 1994 Rwanda genocide emerged from the historical power struggle, both economic and political, in the former Belgian colony (Haperen, n.d.). In three months, between 500,000 to 1,000,000 Rwandans, both Hutu and Tutsi were killed in what the United Nations consider as inhuman acts (Verpoorten, 2005). It was the Tutsi people who first took on the realm to lead Rwanda following the exit of the Belgian colonial government. This made the Hutu tribe feel inferior as their former European confidante in the rule of Rwanda left. Upon the assassination of Rwandan president Juvénal Habyarimana, a Hutu, through a plane crash that was shot down by surface-to-air missiles, the minority Hutu blamed the incident on the Tutsi-affiliated Rwandan Patriotic Front (RPF) despite the lack of a factual investigation. The minority Hutu people were angered by this tragic event. By taking advantage of the uproar and the remaining political power that they had in the country, violence commenced in the widespread killings of the Tutsis. Riots against the latter's presence were common in the country. Most notably, the human rights of women and children were greatly deprived of them (Newbury, 1995). 
Genocide concerns with acts committed, of intent and through capacity, to destroy particular groups and their members. It is manifested not exclusively through killings and harming humanity based on national, ethnic, or religious differences, but often extends to denial of rights, discriminatory practices, unnecessary tensions, and less obvious methods of destruction such as deprivation of food and water. Genocide constructs identities in terms of "us" and "them" to highlight superiority and inferiority. These occurrences perpetuate unjust acts towards targeted groups, exploit their vulnerabilities, and take away their rights and liberties (Verpoorten, 2005).

Twenty-five years since the Rwandan genocide of 1994, this paper would like to revisit the global discourses on the said massacre by looking into the contemporary discussions on the issue. This work investigates the roles of Rwanda's neighboring countries in Africa, the United Nations, and the international community in their responsibility to protect the human rights of the Rwandan population at the time of the crisis. By tracing the historical and discursive developments, this project also examines how reactions and responses to the tragedy helped conceptualize, improve, and carry out the international human rights concept of the 'Responsibility to Protect' (R2P).

The following section will discuss the methodology relevant to the discussion of the developments in the Rwandan genocide and the emergence of R2P in the international human rights scene. The results and discussion section will trace the historical and discursive development of the topics mentioned. Lastly, this study concludes on the contemporary discourses on R2P that emerged in the last decade (2010-2019).

\section{METHODOLOGY}

To complete this pursuit, this work employed the qualitative method of document analysis to identify the primary and secondary sources relevant to the development of this study. Document analysis is essential to qualitatively identify the contexts of the actual experiences of the people being studied, most especially in historical and cultural research (Bowen, 2009). To understand the historical, political, economic, and cultural conflict between the Hutus and Tutsis, we specifically employed document triangulation in the methods to converge information from various sources and come up with a focused theme that is significant in narrating the discourses involved (Carter, Bryant-Lukosius, DiCenso, Blythe, \&Neville, 2014). Moreover, document triangulation mitigates bias and enhances the reach of data saturation as studies employing this method are using multiple sources of data (Fusch, Fusch, $\&$ Ness, 2018). Furthermore, document triangulation is also essential in the validations of themes in qualitative research (Jonsen\&Jehn, 2009) and enhancing the quality and credibility of the study (Patton, 1999).

\section{THE HISTORICAL ROOTS OF RWANDANS}

In the precolonial era, the Rwandan population was composed of three tribal groups: the Hutu, Tutsi, and Twa. The Twa people settled on the area in the sixth century, followed by the Hutu in the seventh century, and the Tutsis in the eighth and ninth centuries. Everyone lived together in the same land, with equal social treatment, the same language, and recognized each other simply as Rwandans. The three peoples had different sources of living that they have enriched in order to survive. The Twa made a living by hunting animals, gathering food, and pottery-making. While the Hutu were considered as crop cultivators. On the other hand, the Tutsi were cattle farmers. But then, hierarchy also rose between the two groups during the reign of King Rwabugiri, a Tutsi, in 1860-1895. The Tutsi conquered and established control over central Rwanda, despite the fact that they are less in number compared to the Hutu. The Tutsi dominated politically, economically, and militarily. This has cost the two inferior groups limited social mobility (Magnarella, 2005). 


\section{EUROPEAN COLONIZATION OF RWANDA}

The ethnic rivalry between the Hutus and Tutsis intensified when the German and the Belgians colonized the country. The culture of favoritism from the colonizers further shaped the superiority of the Tutsis. The colonial years of Rwanda started in 1885 by the German Empire. However, they were not able to fully grasp Rwanda until 1910. Thus, the German governed indirectly, through the local chiefs of Rwanda under the German administrators. When the First World War has ended, Rwanda was transferred under the Belgian colonizers having which losing the possessions of Germany. It was then where Rwanda was ruled under Belgium. Belgians vested their trust in the Tutsis thus giving them the advantage of staying at the top of the hierarchy. In fact, in 1935, the Belgians pushed for the creation of identification cards to distinguish whether one is a Tutsi or a Hutu. Upon achieving independence, the Belgians gave a chance to take the side of the Hutus which dominates the population of Rwanda by 85 percent. It was then when the group Party of the Hutu Emancipation Movement (PARMEHUTU), which aims to remove the barriers and push for a community free from oppression, was supported by Belgian officials and the Roman Catholic Church. But in 1959, when the then Tutsi king died, the purpose of the group changed to overpower the ruling Tutsis. It was supported by the Belgian authorities. Political violence was assumed by vengeance, hatred, and resentment. Riots built up and overpowering the Tutsi government was successful. But, the safety, freedom, and equality, which were initially presented by the PARMEHUTU amongst the Rwandan people were compromised. Displacements and massacres commenced and used the beliefs of the Tutsis against them to justify their actions. This led to the success of gaining power above the Tutsis (Corey \&Joireman, 2004).

\section{SPARK OF THE CONFLICT BETWEEN THE WARRING TRIBES}

The year 1959 marked the death and the birth of rule among the two ethnic groups. The passing of the Tutsi king empowered the will of the Hutus to remove the Tutsis from power. The PARMEHUTU leaders declared a social revolution which took a toll on the lives of the Rwandans. This came to the realization of ending the colonial powers by the Belgians. An election was held afterward, with the participation of both Tutsis and Hutus. In the 1960 elections, the Hutu won and finally gained power over the country. Many Tutsis were killed, robbed of their possessions, took their homes, and forced to flee after the results were released (Haperen, n.d., p.100). When the Hutu finally gained power and manipulated ethnic divisions, the Hutus had their break to rule over the Tutsis. They now reigned as the superior in the entire domain of Rwanda. The tables have completely turned and Tutsis were put under the control of the Hutus. Tutsis were seen as the enemy of the Hutus, outsiders, and oppressors of Rwanda (Nikuze, 2014, p.1091). During those days, the Hutus had their view of the Tutsis as "inyenzis" which meant cockroaches that had to be exterminated. The term was instilled publicly by Rwandan magazines and by the famous radio station, Radio Television Libre des Mille Collines which means Free Radio Television of the Thousand Hills, during the period of the genocide (Ndahiro, 2014). The title put for Tutsis played a big role in pursuing violence. Violence against the Tutsis remained until the 1970s and the 1980s and fully established the well-seen divide among the Hutus and the Tutsis.

Rwandans who fled to Burundi, which was also divided into the two ethnic groups, experienced killings between the Hutus and the Tutsis, as well, with the dominance of the Tutsis. This strengthened the hatred of the Hutus against the Tutsis and fostered the anti-Tutsi ideology of the Hutus. This led to the rise of Habyarimana of MRND, also known as the Hutu of the North, an extremist Hutu, to extend the efforts of exterminating the Tutsis. However, Kayibanda of PARMEHUTU and his political leaders were killed along with the other Tutsis. Massacres and murders continued until the 1970s to 1980s. Membership in MRND became mandatory for all Rwandans and Habyarimana stayed in the position from 1978 to 1988, with three re-elections, for the sole reason of being the only candidate to run for the position. 
Habyarimana stuck to the system of the ethnic divide. In 1990, another significant event happened concerning the two groups. The RPF invaded Northern Rwanda. This manifested a sign of attempting to overthrow Habyarimana and to regain their right to return to Rwanda. The group initially blended in with the Tutsis to pave way for the other Tutsis' return. When they were able to finally settle, they declared their occupation of Northern Rwanda. The attacks from the RPF posed fear and threat to the Rwandan government. The Rwandan army fought the RPF which, again, caused the lives of Tutsis and Hutus. Even so, the purpose of the RPF was successfully insinuated and started the downfall of Habyarimana's government (Verwimp, 2017).

In 1992, the RPF was halted and negotiations started. The United Nations has given its attention to the issue and was able to present the Arusha Accord, an agreement that deals with power-sharing, aiming to end the crisis and civil war peacefully. With Habyarimana's authority crumbling, he then signed the Arusha Accord which was an agreement to share powers with the RPF (Tarr, 2015). This, definitely, caused displease to the Hutu extremist followers. The Tutsis then became a scapegoat in Rwanda. With the approval of Habyarimana, the Tutsis were blamed and criminalized by the Hutu people. The local newspaper also released the 'Hutu Ten Commandments' as a guide for the Hutus to follow and justify their unnecessary and grievous actions towards the Tutsis. The Hutu Ten Commandments convinced the Hutu people to pursue hate among the Tutsis and sent false intentions and non-existent RPF plans of oppression, slavery, and injustice by the Tutsis returned in Rwanda. The Rwandan government made sure that their message reaches all individuals and from it, they must act accordingly (Magnarella, 2005, p. 810).

The series of events sparked the flame between the two ethnic groups which prevailed and resulted in the Genocide of 1994. The building up of the inequality led by the president itself has tolerated discrimination and violence towards each other. As time passed, even other politicians and businessmen have joined the chaos which in a result caused havoc among everyone. The competition for power led to a large-scale moral outrage among the people of Rwanda.

\section{THE RWANDAN GENOCIDE OF 1994}

The Rwandan Genocide of 1994 was the event of mass killings of approximately 800,000 Tutsis. The killings lasted in just three months, yet the casualties were very high. For that to be possible, one has to kill one person in twelve seconds, five people every minute, three hundred every hour, and seven thousand and two hundred a day (Shattuck, 2005). The number of people who were directly involved in the slaughter was about 175,000 to 210,000 (Rothbart \& Cooley, 2016). On the 6th of April, 1994, the presidential plane was shot down and crashed. Inside was the then-president Habyarimana, the chief-of-staff of the Rwandan army, the president of Burundi, and other political Rwandan authorities. This has caused political instability and complete loss of order among the citizens of Rwanda. Therefore, political activites implemented to unite the Rwandans were neglected and the sentiment that the Hutus area above the Tutsis emerged. Consequently, all steps taken to create peace and order in Rwanda were marginalized. Tutsis, in general, were forced to leave their homes immediately. While the people who planned the incident remained unknown, the Hutus blamed the Tutsis for the presidential killing. However, there were also people who believed that the crash was made by Habyarimana's people, the extremist Hutus. It was a well-planned act to initiate genocide, orchestrated by the Hutus to fully erase the Tutsis (Sarkin\& Fowler, 2010).

An hour following the crash, Hutu military men blocked roads and asked for identity cards to distinguish the Hutus and the Tutsis. Radio stations also announced the plan to kill all the Tutsis regardless of their age, gender, and social situations to promote collective accomplishment guilt-free. Neighbors attacked their neighbors, colleagues attacked their colleagues, teachers and students attacked each other, doctors killed their patients, and so the 
list goes on with the killings. The genocide did not stop with the killings. Hutu men raped, tortured, and mutilated women, before killing them. This includes pregnant women to prevent the birth of their children (Magnarella, 2005, p.815). Inrural areas, farmers were murdered with the use of machetes, spears, knives, and wood with nails or screwdrivers exposed. In three months, $11 \%$ of the Tutsis were killed which set the record for the largest number of people killed in a short span of time (Haperen, n.d., p.110).

\section{THE RESPONSIBILITY TO PROTECT}

The Responsibility to Protect ( $\mathrm{R} 2 \mathrm{P}$ ) is a principle in international relations that seeks to prevent war crimes, ethnic cleansing, crimes against humanity, and genocide. In addition, it raises the point of the obligation and the responsibility of states to protect states or the people under the cases abovementioned. When an individual state is not capable of protecting its state and its citizens anymore, the international community now has the right empowered by their will to give assistance and alleviate them from the mass atrocities they are subjected to. The concept of responsibility to protect was a lesson learned from what happened in Rwanda in 1994. Kofi Annan, the then secretary-general of the United Nation, brought about the attention of the international community to have a plan and solution that would fit to be called a humanitarian intervention. The responsibility to protect is a call for the leads that would tell the states of their capacity and freedom to provide help to those who are in need and to protect them from the further experience of any from the abovementioned. Once the state is evidently unable to protect itself and its people, the international community shall assume the responsibility to save the people (Asia-Pacific Centre for the Responsibility to Protect, n.d.). In the case of Rwanda, during the genocide, the United Nations saw the situation of Rwanda to be too risky to get involved. The organization and the other states then turn a blind eye to what was happening in Rwanda. The bloodshed, the depleting population, and the cry for help seemed to be condoned by the international community (Fisseha, 2012).

The United Nations lacked the effort to intervene during the Rwandan Genocide that could have ceased and saved more people during its occurrence. The insufficiency of mandates to eradicate the killings and to protect the victims caused the weakening of the UN Peacekeeping Mission in Rwanda. The mission forbids the use of force needed for protection. In fact, it was only limited to observing and investigating the possibility of a cease-fire, and completely excluded intervention. Despite given reports about the risk of genocide and its increasing number, the assessment was ignored upon the reasoning that it was insufficient. This only shows the incompetence of the organization is trying to prevent the mass slaughter from persisting (Winfield, 1999). The international community also showed slim to none support demonstrating the will to help and stop the mass atrocity that was happening in Rwanda at that time. Upon realization, this has served as a lesson learned for the United Nations and the international community to intervene when it is needed. The R2P provided tenets to be followed once events like this happen again. The intervention of states when the four types of crimes took place, the intervention of the state to build warning through mediation and negotiation, and the responsibility to intervene with military measures (Bellamy, 2009).

\section{REVISITING THE CASE AFTER 25 YEARS: CONTEMPORARY DISCOURSES ON R2P}

Dorn and Matlofff (2000) argued that the Rwandan genocide could have either been prevented or mitigated by the United Nations as the preconditions to a civil war in the country were already indicative of the historical conflict between the Hutus and the Tutsis. For them, the lack of international political will by the United Nations Security Council was at fault as all the diplomatic, humanitarian, and military efforts were ready to adapt to the conflict in Rwanda. They also mentioned that the "world community owes it to the hundreds of 
thousands of innocent human beings who were slaughtered during the Rwandan genocide to try to predict and prevent future genocides."

Rothbart and Cooley (2016) found that Hutus were actually providing aid to the Tutsis during the conflict. Informants of their study mentioned that it was the propaganda by the Hutu leadership that propagated misinformation that Tutsis are different from them. Moreover, they also emphasized that because of their Christian moral education, they recognize the moral values and vulnerability of everyone, and may they be Hutu or Tutsi.

Kassner (2014) mentioned that the international community had the moral obligation and responsibility to protect the human rights of all of humanity. As such, global intervention in the conflict could have prevented the massive violation of human rights cases during the genocide. It is essential that the international community recognize such events. Upon the ability to observe and study the current happenings and its implications, it is only then that possible solutions could be built up, as well as its implementation.

Puddington (2019) argued that mass atrocities, such as that of the Rwandan genocide, could happen again as there is a trend of global decline in democracy following the rise of authoritarian leaders. For him, there is an ongoing international failure to protect the human rights of the people and that the international community has not applied what they learned from Rwanda.

The United Nations reflected on the international community's failure to intervene in the Rwandan genocide. The United Nations Secretary-General Antonio Guterres mentioned that, indeed, the international community failed in preventing the atrocity to happen. $\mathrm{He}$ also expressed concern about cases that are similar to the Rwandan genocide, such as the killings and torture of Rohingya Muslims in Myanmar. He added that "states have a fundamental responsibility to protect their populations from genocide, war crimes, ethnic cleansing and crimes against humanity" (United Nations, 2018).

\section{CONCLUSION}

Differences shall never be a reason to spark a war, no matter what factor it holds. Ethnicity, religion, race, should not incite violence among each other. Let all the mass atrocities that have happened serve as a lesson and give the message of averting the adverse engagement in war. Inhumane acts should be resolved immediately in accordance with the responsibility to protect the states. The protocol of the responsibility to protect shall present itself as a useful means of fixing disharmony, friction, and division among the members of states. The responsibility to protect must actively prove its purpose to protect people from torture, slavery, war crimes, and genocide.

\section{REFERENCES}

Asia-Pacific Centre for the Responsibility to Protect. (n.d.). What is the Responsibility to Protect? Basic Information. Retrieved from Responsibility to Protect: Basic Information. Retrieved from https://r2pasiapacific.org/files/310/R2P basic information_english.pdf.

Bellamy, A. (2009). Responsibility to Protect: The Global Effort to Mass Atrocities. Cambridge: Polity Press.

Bowen, G. A. (2009). Document Analysis as a Qualitative Research Method. Qualitative Research Journal, 9(2), 27-40. doi: https://10.3316/qrj0902027

Carter, N., Bryant-Lukosius, D., Dicenso, A., Blythe, J., \&amp; Neville, A. J. (2014). The Use of Triangulation in Qualitative Research. Oncology Nursing Forum, 41(5), 545-547. doi: https://10.1188/14.onf.

Corey, A. \&Joreiman, S.F. (2004). Retributive justice: The Gacaca courts in Rwanda. African Affairs, 103(410), 73-89. doi: https://10.1093/afraf/adh007. 
Dorn, A. W., \&Matloff, J. (2000). Preventing the Bloodbath: Could the UN have Predicted and Prevented the Rwandan Genocide ?. Journal of Conflict Studies, 20(1). Retrieved from https://journals.lib.unb.ca/index.php/JCS/article/view/4333.

Fisseha, M. (2012). Responsibility to Protect: Rwanda and International Law. The Scientific Journal for Theory and Practice of Socioeconomic Development, 1, 44-51.

Fusch, P. I., Fusch, G. E., Ness, L. R. (2018). Denzin's paradigm shift: Revisiting triangulation in qualitative research. The Journal of Social Change, 10(1), 19-32. doi: https://10.5590/JOSC.2018.10.1.02

Haperen, M. (n.d.). The Rwandan Genocide, 1994. Instituutvooroorlogs-, holocaustengenocidestudies. $\quad$ Retrieved from https://www.niod.nl/sites/niod.nl/files/Rwandan\%20genocide.pdf

Jonsen, K., \&amp; Jehn, K. A. (2009). Using triangulation to validate themes in qualitative studies. Qualitative Research in Organizations and Management: An International Journal, 4(2), 123150. doi: https://10.1108/17465640910978391

Kassner, J. (2014). The Moral Obligation to Intervene in Rwanda. E-International Relations. Retrieved from https://www.e-ir.info/2014/04/16/the-moral-obligation-to-intervene-in-rwanda/.

Magnarella, P. J. (2005). The Background and Causes of the Genocide in Rwanda. Journal of International Criminal Justice, 3(4), 801-822. doi: https://10.1093/jicj/mqi059.

Newbury, C. (1995). Background to Genocide: Rwanda. Issue: A Journal of Opinion, 23(2), 12-17.

Nikuze, D. (2014). The Genocide against the Tutsi in Rwanda: Origins, causes, implementation, consequences, and the post-genocide era. International Journal of Development and Sustainability, 3(5), 1086-1098.

Ndahiro, K. (2014). Dehumanisation: How Tutsis were reduced to cockroaches, snakes to be killed. The New Times Rwanda.Retrieved from https://www.newtimes.co.rw/section/read/73836\#: :text=In\%20the\%20years\%20leading\%20 up,now\%20called\%20inyenzi\%20(cockroach).\&text=All\%20Tutsi\%20men\%2C\%20women $\%$ 20and,of\%20a\%20nation\%20but\%20cockroaches.

Patton, M.Q. (1999). Enhancing the quality and credibility of qualitative analysis. Health Services Research, 34(5), 1189-1208.

Puddington, A. (2019). A Quarter-Century after Rwanda's Genocide, Mass Atrocities Continue to Multiply. Freedom House. Retrieved from

https://freedomhouse.org/article/quarter-century-after-rwandas-genocide-mass-atrocitiescontinue-multiply.

Rothbart, D., \& Cooley, J. (2016). Hutus Aiding Tutsis during the Rwandan Genocide: Motives, Meanings, and Morals. Genocide Studies and Prevention, 10(2), 76-97. doi: https://10.5038/1911-9933.10.2.1398.

Sarkin, J. \& Fowler, C. (2010) The Responsibility to Protect and the Duty to Prevent Genocide: Lessons to be Learned from the Role of the International Community and the Media During the Rwandan Genocide and the Conflict in the Former Yugoslovia. Suffolk Transitional Law Review, 33(1), 35-86.

Shattuck, J. (2005). The Collective International Responsibility to Protect: The Case of Rwanda. Northwestern Journal of International Human Rights, 4(1), 105-117.

Stanton, G. (1998). The 8 Stages of Genocide. Genocide Watch. Retrieved from http://www.genocidewatch.org/aboutgenocide/8stagesofgenocide.html

Tarr, A. (2015). Arusha Accords: Rwanda [PowerPoint Presentation]. Retrieved from https://dx.doi.org/10.13140/RG.2.1.1122.8887

United Nations. (2018). On Rwandan genocide anniversary, UN leaders ask: Can world muster the will to prevent new atrocities?. Retrieved from https://news.un.org/en/story/2018/04/1006732.

Winfield, N. (1999). UN Failed Rwanda. Global Policy. Retrieved from https://www.globalpolicy.org/component/content/article/201rwanda/39240.html\#: :text=United\%20Nations\%20\%2D\%20A\%20report\%20assessing, Rwan dan\%20people\%20when\%20they\%20most.

Verpoorten, M. (2005). The Death Toll of the Rwandan Genocide: A Detailed Analysis for Gikongoro Province. Population, 60(4), 331-367. doi: 10.3917/popu.504.0401

Verwimp, P. (2017). Peasant Ideology and Genocide in Rwanda Under Habyarimana. Genocide in Cambodia and Rwanda, 1-40.

doi: $\underline{\text { https://10.4324/9780203790847-2 }}$ 